\title{
Symptomatic Mandibular Fibrous Dysplasia With Concurrent Triple X- and Premutation Stage Fragile-X-Syndrome: Case Report With Short Literature Survey
}

\author{
REINHARD E. FRIEDRICH ${ }^{1}$, FELIX K. KOHLRUSCH ${ }^{1}$ and ANDREAS M. LUEBKE ${ }^{2}$ \\ ${ }^{1}$ Oral and Craniomaxillofacial Surgery, Eppendorf University Hospital, \\ University of Hamburg, Hamburg, Germany; \\ ${ }^{2}$ Institute of Pathology, Eppendorf University Hospital, University of Hamburg, Hamburg, Germany
}

\begin{abstract}
Background: Certain constitutive chromosomal abnormalities of the human $X$ chromosome are relatively common in conspicuous neuropsychiatric findings. Although tumors or tumor-like lesions are occasionally reported in diseases of the $X$ chromosome, they are numerically negligible, for example, in aneuploidy such as the triple $X$ syndrome (TXS). Case Report: A 16-year-old female patient with a known TXS and premutation stage of fragile $X$ syndrome was referred by her dentist for diagnosis and treatment of unilateral cheek swelling. The examination of the psychologically conspicuous patient revealed a unilateral mandibular tumor with dysesthesia of the mental nerve. Surgical removal of soft, crumbly spongiosa over the nerve canal resulted in sufficient pressure release of the constricted nerve and restoration of epicritic sensitivity. Imaging findings and histological and molecular genetic examination revealed monostotic craniofacial fibrous dysplasia. Conclusion: Although the data in the literature do not give reason to suppose an accumulation of neoplasms in TXS, a numb chin syndrome should be a reason for detailed diagnostics. Careful diagnosis allows for customized therapy. This is the first report on the coincidence of TXS, fragile $X$ syndrome, and fibrous dysplasia in a single individual.
\end{abstract}

Numerical aberrations of chromosomes are relatively common in human reproduction and viable only in certain constellations

Correspondence to: Professor R. E. Friedrich, MD, DMD, Ph.D., This article is freely accessible online.

FEBOMFS, Department of Oral and Craniomaxillofacial Surgery, Eppendorf University Hospital, University of Hamburg, Martinistr. 52, 20246 Hamburg, Germany. Tel: +49 40741053259, e-mail: rfriedrich@uke.de

Key Words: Triple $\mathrm{X}$ syndrome, fragile $\mathrm{X}$ syndrome, fibrous dysplasia, GNAS1 mutation, numb chin syndrome.
(1). Viable aneuploidy of the sex chromosomes leads to variable phenotypes with different impacts on health and quality of life (2). Triple X syndrome (TXS) is a sex chromosomal abnormality (3). TXS is a relatively common occurrence in humans, with the estimated incidence being one in 1,000 females (4-6). TXS is relatively often associated with intellectual and psychological disabilities of affected individuals $(5,6)$. On the other hand, affected individuals can be of normal physical and mental health $(3,5)$. Indeed, genotype-phenotype relationships remain to be defined (3). Most reports about TXS focus on neurodevelopmental disorders $(5,7)$. However, other features such as malformations and metabolic alterations (7-11), and immunological diseases (8) are also part of the TXS spectrum. The relationship between TXS and neoplasms has barely been studied. Given the frequency of TXS in the general population, the low number of reports of neoplasms in this syndrome is at least notable. The few publications on TXS and neoplasms so far are case reports and concede that it might be a chance or coincidence (12-16) or consider the potential influence of mosaic or constitutional TXS status on immunological therapies (17-18).

As well as numerical aberrations, the $\mathrm{X}$ chromosome may show other alterations with potential effects on phenotype (19). A relatively common mutation is named after a pathognomonic cytogenetic phenomenon that can be identified in the nucleus of affected individuals during preparations to determine the karyotype $(20,21)$. The affected X chromosome gives the erroneous impression of a localized unstable shape and thus is called fragile X syndrome (FXS) $(22,23)$. The phenotype was already known from clinical studies (24) and is also known under the eponym Martin-Bell syndrome (25). FXS occurs in men and women, with lower frequency in males (26). Pathfinding symptoms of diagnosis are attentiondeficit/hyperactivity disorders and learning disabilities (27, 28). However, the connection between a genetic disposition and learning difficulties is often recognized late $(29,30)$. FXS is a neglected cause of impaired learning disorders and, according to the general view (31), probably the most 
common monogenic disorder associated with impaired intellectual ability after Down syndrome (32). However, FXS has a significant range of clinical findings, and emphasis is given to marked heterogeneity $(28,31)$. The combination of certain physical features can substantiate the suspected diagnosis (33). Molecular genetic research has shown the cause of the cytogenetic finding is a mutation of the fragile $\mathrm{X}$ mental retardation 1 (FMRI) gene (main location: Xq27.3), leading to massive replications of a distinct base triplet (CGG) (34-38). Thus, FXS belongs to the group of trinucleotide repeat disorders $(35,36)$. However, the deletion of FMRl can also cause the FXS phenotype in rare cases (39). A lower number of replications $(<59)$ does not appear to affect the carrier's phenotype. Individuals carrying about 59 to $200 \mathrm{CGG}$ repeats define the premutation stage that is associated with diverse findings, in particular, neuropsychiatric disorders (40). Individuals with about 200 or more repetitions very likely will show the full range of findings (34). Interestingly, it has been suggested that FXS is associated with a lower risk of developing cancer $(41,42)$, but these relationships have been controversially discussed (43). Indeed, an increased risk of developing lip cancer in FXS was estimated (43). Furthermore, increased FMRI mRNA levels have a negative prognostic effect in certain forms of breast cancer (44). Other reports of FXS and malignant neoplasms are likely the results of coincidences of various genetic events $(45,46)$. However, those individuals reported are strikingly often children and adolescents (47-52).

Differential diagnosis of TXS before definitive karyotype results are available includes FXS, among other mutations (3). The concurrence of TXS and FXS has been reported but appears to be rare (53-55). Concerning potential bone pathologies, genetic influences on bone metabolism are of great importance in both syndromes $(10,56,57)$. The coincidence of TXS or FXS with bone tumors has been registered only very rarely (12).

The following report is of a patient with known TXS and premutation stage FXS who required diagnostic and therapeutic measures due to visible and symptomatic facial tumor development.

\section{Case Report}

Medical history. The 16-year-old female patient was referred for examination and treatment an unclear swelling in the area of the right lower jaw (Figure 1A). The hardly communicative patient was accompanied by her parents for examination. The parents informed the attending surgeons that their daughter was suffering from genetically proven FXS and also TXS. The medical reports confirmed the triple $\mathrm{X}$ karyotype of the patient and a CGG repetition rate of the FMRl gene slightly higher than normal (62 2 repetitions). Evaluation of the latter genetic finding explicitly emphasized that the patient's known behavioral disorders were not explained by the mutation status of the gene.

In the present case, a relatively short and flat forehead was noted in relation to the pronounced midface and chin region (Figure 1B). However, the sagittal relationships of a mandibular prognathism were not present (Figure 1C). The ears were slightly prominent. It was striking that it was practically impossible to establish any eye contact with the patient, and the medical contact had to be largely mediated through the parents.

For some time, the lower right cheek region had been swollen, and the patient had occasionally complained about pain. Visual inspection of the small patient revealed an inconspicuous external condition of the skin and facial motor functions. When palpating the face, the side of the right lower jaw was more prominent than the left lower jaw, in particular concerning the region of the right inferior border. The patient indicated a hyposensitive skin area that could be traced over the right cheek side distal to the nasolabial fold. The lips showed equally normal sensitivity to tactile stimuli, but the right chin region was less sensitive to touch than the left. The mandibular body showed no pain on pressure in the region of interest and symmetrical response on the mental foramina. Teeth were completely developed, had emerged to the oral cavity, and completed the dental arch in a symmetrical fashion. Teeth were well maintained, non-mobile, adequately responsive to cold stimuli, and the oral mucosa was rosy and intact. However, the mandibular body in the posterior region of the right side felt significantly enlarged to the lateral side without the oral vestibulum being elevated (Figure 1).

Radiology. A panoramic view radiography showed the vertical asymmetry of the mandibular corpus in favor of the right side (Figure 2A). On the right side of the mandible, the bone marrow was of gray-clouded radiopacity and had lost the trabecular structure. The contour of the deformed lower jaw was preserved, as well as the integrity and position of the teeth in the alveolar bone. An ill-defined radiotranslucent region was depicted within the radiopaque lesion, immediately below the molars and approximately opposite the region from which the patient indicated feeling diminished sensitivity of the skin.

Cone-beam computed tomography of the right lower jaw showed a hyperplastic, predominantly homogeneous radiopaque cancellous bone region, which was interrupted by focal peri-radicular radiotransparent areas (Figure $2 \mathrm{C}-\mathrm{H}$ ). The nerve canal had a smaller diameter on the affected side than on the left side (Figure 2C-E). Both nerve channels ran horizontally at the same height (Figure 2A and C-E). Only in the area of the mental foramina, there was asymmetry of dimensions of the bone channels in which, on the lesion side, an elongation of the terminal branch of the alveolar nerve was evident in the transversal plane (Figure 2E). The 


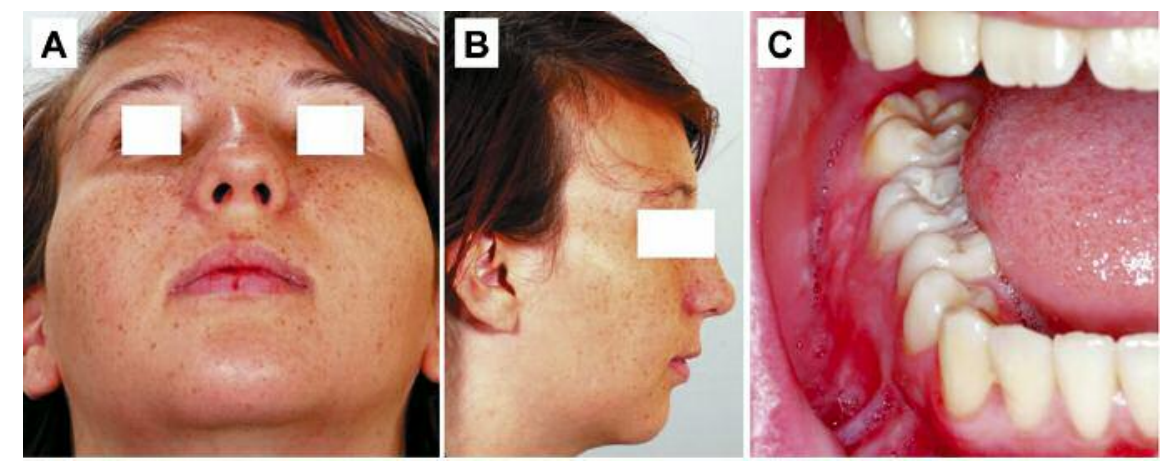

Figure 1. Facial aspect of patient. A: Enlarged interorbital distance and asymmetry of lower facial region with prominent right mandibular angle. B: Flat frontal region and relative long midfacial and lower face. C: Oral aspect reveals inconspicuous right lower alveolar process and vestibule.

increased bone volume caused by the lesion was, according to radiological findings, largely due to the expansion of the bone in the direction of the vestibular side (Figure $2 \mathrm{~F}$ and $\mathrm{G})$. The bony limitation of the nerve channel was no longer continuously detected in the area of the radiolucent region (Figure 2G and $\mathrm{H}$ ).

Scintigraphy was performed to check whether the lesion was monostotic or polyostotic (Figure 3A-D). Scintigraphy revealed the intensified metabolism of the right side of the lower jaw as a solitary finding. The suspected diagnosis was malignant disease or osteonecrosis.

The radiological aspect of the lesion suggested fibrous dysplasia (FD), but several differential diagnoses had to be considered. Furthermore, the association of the lesion with the patient's genetic disposition was unclear.

Surgery. It was decided that a bone sample would be obtained to determine the nature of the bone lesion. The osteolytic area beneath the molars was also to be examined, and the canal relieved of compression by the lesion. Under general anesthesia, the muco-periosteum of the right lower jaw's vestibulum was lifted off. Below was an inconspicuous cortex. By means of piezo-surgery, a block of bone was removed from below the roots of the right molars (Figure $3 \mathrm{E}$ ), and the mandibular canal was exposed. During this preparation, crumbly cancellous bone appeared below the cortex and was removed from the edge of the nerve canal. This area corresponded to the radiological transparency at the apices of the molars. The exposed alveolar nerve was intact, of normal size and, after removal of the altered bone in the remaining canal, without any adhesions to be removed. The bone barely bled during the procedure. Wound healing was unremarkable (Figure 2B). Eight weeks later, the patient described that the discomfort of the right cheek had disappeared. Likewise, the epicritic sensitivity of the lip and chin skin was intact.
Histology. The examination of the bone showed the typical features of FD (Figure 4A). In addition, the tissue was prepared for DNA extraction and amplification of the gene coding for guanine nucleotide-binding protein, alphastimulating activity polypeptide 1 (GNAS1) for mutation on codon 201 (exon 8). The lesion showed the c.602G $>A$ (p.R201H) mutation (Figure 4B). This mutation provides evidence in the tissue sample for the phenotype called FD. Murine double minute $2(M D M 2)$ gene amplification in the bone sample was excluded (58).

\section{Discussion}

This report shows the coincidence of a somatic mutation resulting in tumor-like bone growth in an adolescent female with X-chromosomal aberrations. This coincidence of findings has not been described so far. Unusual in this case was the course of the diagnosis, because due to the knowledge of the genetic disease of the patient, it was essential to assess the clinical findings accurately as well as to take into account that the findings might have been independent of the underlying disease.

It is well-known that aneuploidy is a regular feature of the malignant phenotype arising from cells that were subjected to somatic mutation (59). In contrast to somatic aneuploidy, viable constitutional aneuploidy is rare (60). When examining the relationship of constitutive aneuploidy and the emergence of neoplasms, a careful distinction is made between autosomal and sex chromosomes. Neoplasms in constitutive aneuploidy arising in autosomes are, for example, transient myeloproliferative disorder or full-blown acute myeloid leukemia in patients with trisomy 21 . In patients with sex chromosomal abnormality, the tendency to develop neoplasms is mainly due to increased tumor formation in Turner syndrome $(45, \mathrm{X})$ and Klinefelter syndrome $(47, \mathrm{XXY})$ (60). However, in both these $\mathrm{X}$-chromosome-linked 

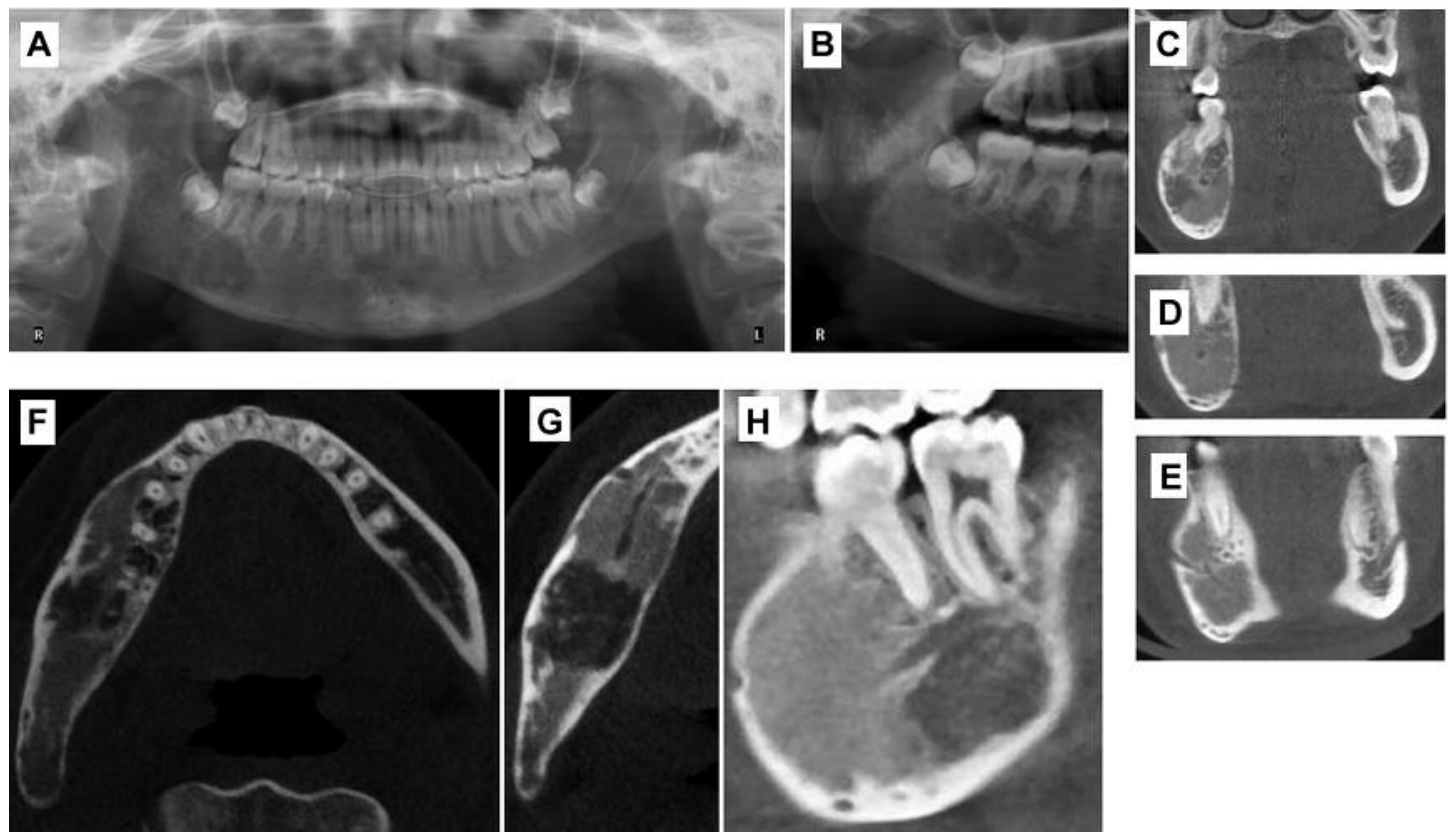

Figure 2. Radiology of mandibular fibrous dysplasia. A: Panoramic view of jaws prior to surgery. No disturbance of habitual intercuspation of the teeth by the bone tumor of the right mandibular side; enlarged mandibular corpus below the roots of the teeth, central hypodense region below the right lower second molar, markedly enlarged jaw angle on the right side. The milky-glass-like radiopacity has blurred borders and extends mesially to the premolars, dorsal in the mandibular ramus. B: Panoramic view (cropped image) of the osteolysis region after decortication of the mandible on the vestibular side. C-E: A series of consecutive cone beam computed tomographs (CBCT) of the jaws prior to surgery (transverse sections through the first molar to premolar region in the posterior-anterior direction). C and D: The vertical position of the mandibular canal remains largely unchanged in its anterior-posterior course and diameter. The radiopaque tumor mass lies concentrically around the canal, which is partially bordered by a sclerotic rim. E: In contrast, the canal of the mental nerve is extended on the side of the bone tumor in the horizontal plane. F: Axial section of the lower jaw on CBCT. The dental arch remained unaffected by the bone tumor. Central, irregularly shaped, hypodense areas are scattered within the lesion and in contact with the tooth roots of the right molar, premolar and canine. The cortical layer of the bone is preserved in the tumor area in continuity. G: Axial section of right mandibular side on CBCT a little further caudal than shown in Figure F (cropped image). Motheaten-like transition zone of hyperdense tumor border with conserved nerve canal to the more distal area of extensive osteolysis. However, in the central hypodense area the nerve canal is not completely recognizable. H: Sagittal projection of the hypodense zone of the right side of the lower jaw. The nerve canal's caudal border is missing in the area of the second molar. The tooth roots have a natural shape and are intact.

syndromes, the study also showed a lower incidence of certain neoplasms in patients with gonosomal aneuploidy compared to the respective control group (60). TXS patients are not listed in the discussion of cancer and other tumors and sex chromosomal constitutive aneuploidy (60).

\section{Fibrous Dysplasia}

Genetics. FD is a non-tumorous bone disorder that is characterized by the overproduction and deposition of a poorly organized fibro-osseous matrix, slowly replacing the normal cancellous bone $(61,62)$. The disorder is caused by a mutation of the GNAS1 gene on chromosome 20 (63-65). It is believed that the disease is viable in humans only as a somatic mutation. It follows that in a patient with this mutation, the more cells the mutation captures, and thus potentially the more organs, the earlier the defining genetic change has occurred in ontogenesis $(66,67)$. The phenotype is correspondingly variable (68). McCune-Albright syndrome is based on GNAS1 mutation happening early during embryogenesis and resulting in a phenotype characterized by significant endocrine dysregulation in addition to metabolic bone and pigmentation disorders (69). For skeletal manifestations of the GNAS1 mutation, an influence of the bone metabolism by gene product Gs alpha on the parathyroid receptor is assumed (64). In osteoclasts, adenylyl cyclase is activated, and consequent increased production of cyclic adenosine monophosphate stimulates the proliferation, differentiation, and overproduction of poorly organized fibro-osseous tissues (70-72).

Radiology. Radiographic imaging of craniofacial FD is considered typical, showing a radiopaque lesion described with different metaphors such as sclerotic, ground-glass, or 
A

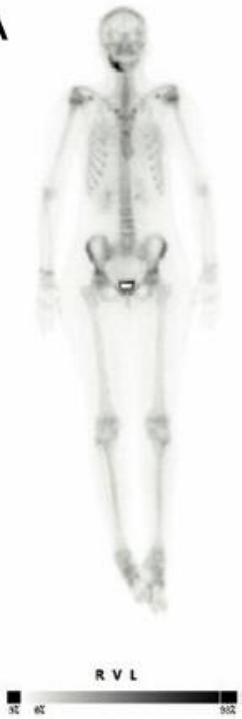

B

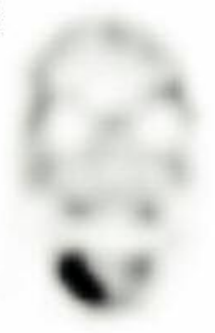

D

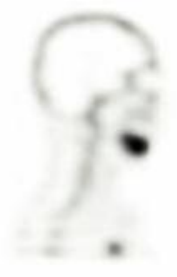

C

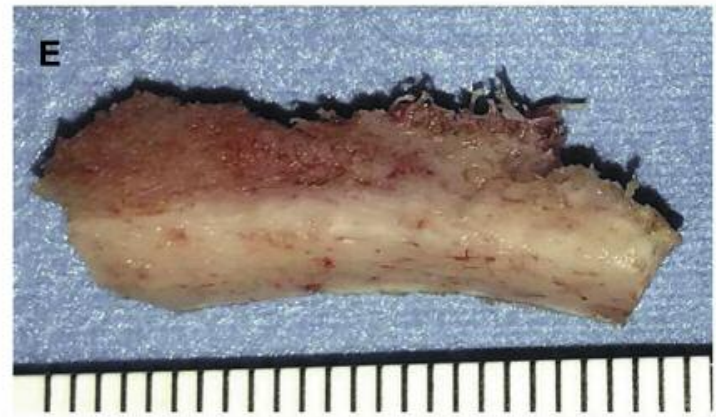

Figure 3. Bone scintigraphs and specimen. A: Whole-body bone scintigraphy with monostotic findings. Selected scintigraphs of the skull depict the mandibular lesion in frontal $(B)$, axial $(C)$, and lateral $(D)$ views. E: Resected specimen of the lower jaw with millimeter scale. Typical cancellous, easy-to-cut bone with a fibrous cut surface.

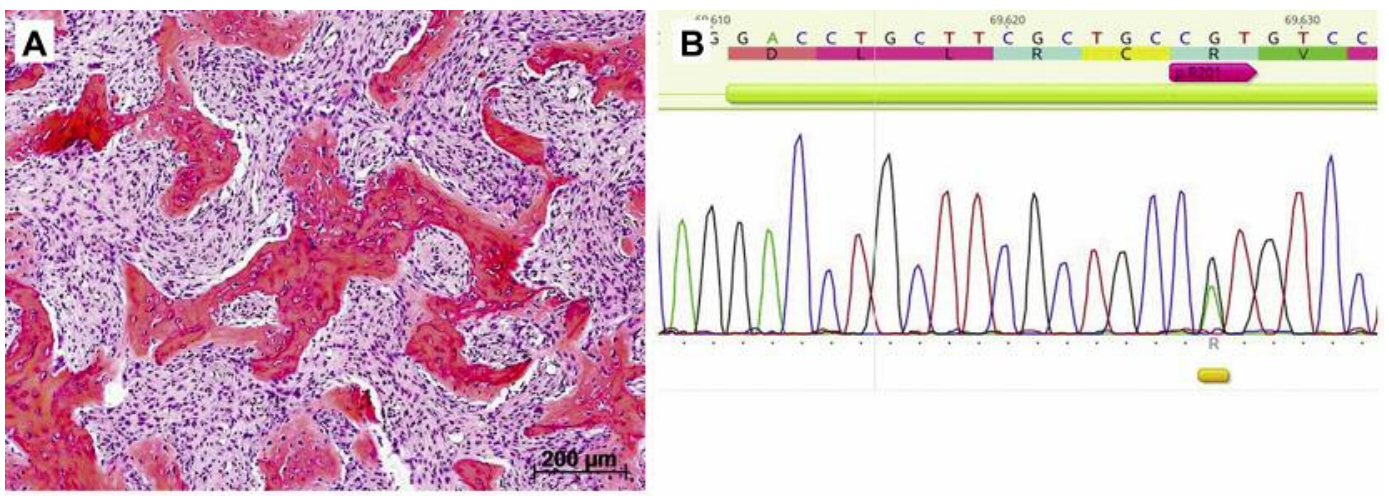

Figure 4. Histological and molecular genetic findings. A: Hematoxylin-eosin stained specimen of the mandibular lesion shows a lesion of immature woven bone trabeculae that seem to arise directly from a moderately cellular stroma of spindle cells with bland, tapered nuclei, and an inconspicuous, eosinophilic cytoplasm. The cells did not display any atypia. B: Ancillary molecular testing revealed a characteristic mutation at codon 201 within exon 8 of the guanine nucleotide-binding protein, alpha-stimulating activity polypeptide 1 (GNAS1) gene located on chromosome $20 q(c .602 G>A ; p R 201 H)$.

peu d'orange appearing. The lesion's margins are ill-defined. Cortex is usually absent in FD. In mandibular cases, FD affects predominantly the post-mental region (73). Cyst-like lesions within a bone are well-known in FD (66). Nuclearmedical diagnosis of FD is not unique (74-76). Scintigraphy was an effective diagnostic measure in the presented case for classifying FD as monostotic. Indeed, scintigraphy is a strategy for locating polyostotic FD (73). However, no decision was made based on scintigraphy in assessing whether the lesion was benign. The differential diagnosis of inflammatory or neoplastic bone changes may be difficult in cases of FD (76-81). Malignant degeneration of FD is rare 
(82-91). However, reports of malignancy arising from FD suggest the affected body region should be under long-term monitoring $(90,91)$. Patients with FD have an increased risk of developing breast cancer (92).

Dentition. Although craniofacial FD may cause malocclusion of the teeth, and some teeth may be displaced by the growth of FD (93), changes in dental arch curvature are not a regular sign of this entity (94).

Disorders of the cranial nerves. The most important complication of craniofacial FD in terms of functional impairment of cranial nerves is the compression of altered and growing bone on the optic canal with consequent obstruction (95). However, it has been pointed out that compression of the nerve canal does not necessarily lead to a reduction in vision. Rather, many cases with craniofacial FD and orbital involvement show that the vision can remain unaffected over a long period of time (96). From this experience, it has been concluded that decompression of the optic canal must be considered very carefully because the risk of iatrogenic nerve damage is inherent to the surgical procedure (96). For the mandibular nerve, isolated hyperesthesia has been described in mandibular FD (97). However, reports of pain in patients with FD are much more common in axial skeletal locations. Pain in craniofacial FD occurs in about $30 \%$ of cases (92). The reduced sensitivity in the terminal branches of the mandibular nerve is unusual in connection with an FD in the bone surrounding the nerve. Rather, this finding should be regarded as a sign of malignant neoplasm if no local findings can adequately explain other causes of this symptom (98-102).

Treatment is overwhelmingly surgical, with modeling osteotomies being preferred over extensive resections (103108). Alternative drug therapies aim to stop rapidly progressive FD (109) but still need long-term evaluation of risks and benefits of anti-resorptive therapy.

Histology. The histological evaluation of the FD is unambiguous in the majority of cases and allows the diagnosis of the disease based on characteristic features under conventional light microscopy (70). However, borderline cases of osteo-pathological assessment have been reviewed in the literature, including manifestations of the jaws (110). The molecular genetic identification of typical mutations of the GNAS1 gene ensures histological diagnosis $(64,111)$.

\section{TXS}

Risk of cancer. Some case reports on the diagnosis and treatment of malignant neoplasm in TXS have been published (12). Therapy and prognosis do not seem to differ from that of a normal population. Bone tumors are extremely rare in TXS patients developing cancer (12). It can be concluded from the few publications on the subject that the diagnosis of TXS was known in a few cases of cancer.

Craniofacial morphology. Targeted analyzes of TXS patients have detected a number of malformations in this group (7, 10). Facial malformations of TXS include cleft lip and palate. However, it was explicitly pointed out that the majority of TXS patients are not diagnosed at all, and the frequencies of the findings in the presented study were considerably influenced by the recruitment method, which necessarily led to a collection of difficult cases (7). Some cephalometric parameters differ in TXS patients and controls. From this, it was deduced that TXS may develop midfacial hypoplasia, becoming evident in the analysis of the sagittal dimension. Likewise, sagittal underdevelopment ('length') of the mandible was found to be more common in TXS than in controls (11). It is possible that TXS patients have a shorter skull base than controls (112). However, anthropometric signs are not so pronounced that a typical phenotype can be derived from these findings.

Dentition. Few studies include oral findings in TXS. The focus of clinical investigations is on the assessment of dental status. Dental disorders were observed in almost half of all TXS patients (7). Here, the need for treatment of many patients is stressed, mainly the rehabilitation of carious dentition. The disorder of facial development with numerical aberration of the dentition is apparently extremely rare in TXS (113), as well as changes in tooth form (114).

\section{FXS}

Risk of cancer. Some reports on the diagnosis and treatment of malignant neoplasm in FXS have been published. A recent survey presented 40 cases (115). Another study describes an increased risk for the development of lip cancer in FXS (43). Therapy and prognosis of FXS patients do not seem to differ from that of a normal population. Bone tumors are extremely rare in FXS patients developing cancer (115). The individual reports of an increased risk of breast cancer in patients with FXS (44) [or FD (92)] suggest that the patient should be advised to undergo regular gynecological examinations at an early age.

Craniofacial morphology. Examinations of the skull in FXS are focused on findings that characterize the phenotype (33). Similarly to TXS, studies on FXS emphasize the reduced facial depth, as well as hypoplasia of the nasal bone cartilage interface, narrow mid-facial width, and exaggerated ear prominence (33). However, even these mild findings are often very discreet, not adequately consistent enough to prove 
all findings in the same patient, and the coincidence of medical findings is also often not very conspicuous. In fact, it was acknowledged that the facial characteristics of FXS are often very subtle (33). In contrast, previous studies on craniofacial anthropology in FXS highlighted the shortened upper face height and increased jaw length compared to sex and age-matched controls (116-118). Further studies provide evidence for cleft lip and palate arising somewhat more frequently in FXS than in the normal population (119).

Sella turcica malformation was reported in two fetuses with FXS (120). The authors detailed a deep sella turcica, notching in the anterior wall, very short dorsum sellae, and irregularly arranged remnants of the notochord in the dorsum. A further study on this subject was performed on lateral cephalograms of FXS patients, revealing normal bone in all five cases of study. However, sella turcica was of normal shape in only one case. Two of the individuals showed deformities of the anterior wall or reduced dorsum height (121). In the case we presented, the anterior wall of the sella turcica was also clearly oblique.

Dentition. In one study, numerical and structural changes in teeth were demonstrated in FXS (122). The dental findings are abnormalities of root morphology, the comparatively early emergence of molars, and a larger jaw angle. However, the correlations of the findings were generally low (122). Earlier studies had shown significantly more frequent malocclusions but no differences in jaw relations and palatal dimensions in FXS (123). Taurodentism was demonstrated in a study in both FXS and TXS (114).

FXS and cherubism. In a case with FXS, a cherubism phenotype was detected (125). This case is interesting because there are overlaps of the phenotype in FD of jaws and cherubism. Cherubism is caused by a mutation of a gene coding for the sarcoma homology 3 domain-binding protein 2 (SH3BP2). SH3BP2 is a protein encoded by a gene located on chromosome 4 (126). FD is a unilocular or multilocular disease with origin in a somatic mutation that potentially affects every bone. On the other hand, cherubism is a hereditary disease with different penetrance but skeletal findings being preferentially located in the jaws. The patient's phenotype with cherubism is characterized by bilateral, spongious hyperplasia of jaws (127). However, unilateral cases of cherubism are also known (126). Therefore, the clinicoradiological findings of unilateral mandibular hyperplasia of the presented case do not exclude cherubism in principle. The histological findings in cherubism and FD are sometimes difficult to distinguish from each other (110). Indeed, cherubism has been called the familial form of FD (127) before the genetic delineation to FD was known. Another monogenetic disease, neurofibromatosis type 1 (NF1), can lead to a cherubism phenotype (128).
TXS, FXS, and FD and other syndromic diseases. Coincidences of NF1 with FXS (129), TXS (130) or FD (131) have been published as case reports. In cases with gonosomal disease and NF1, metabolic and developmental disorders were predominant findings but not the characteristic of $N F 1$ as a tumor-suppressor gene or phakomatosis. The presented patient had no clinical findings pointing to a coincidence with NF1 according to established diagnostic criteria. In patients with FD and NF1, the skin hyperpigmentation pattern differed markedly from the aspect expected in McCune-Albright syndrome. The coincidence of FXS and other syndromes has been reported, e.g. for trisomy 21 (132, 133), and Robin sequence (134).

\section{Conclusion}

FD of the jaw is a rare condition in which the focus is on differentiation from other lesions and tumors. The coincidence of FD with other syndromic diseases is known from individual reports. Therapy is symptomatic and carried out after careful examination of the patient.

\section{Conflicts of Interest}

The Authors declare that there are no conflicts of interest regarding publication.

\section{Author's Contributions}

REF treated the patient, researched the literature, and wrote the article. FKK checked the scientific literature and wrote the article. AML provided morphological and molecular genetic findings and checked the article. All Authors gave final approval for publication.

\section{Acknowledgements}

The Authors would like to thank the patient and her parents for permission to publish the case report.

\section{References}

1 Hassold $\mathrm{T}$ and Hunt P: To err (meiotically) is human: The genesis of human aneuploidy. Nat Rev Gen 2: 280-291, 2001. PMID: 11283700 . DOI: 10.1038/35066065

2 Hall H, Hunt P and Hassold T: Meiosis and sex chromosome aneuploidy: how meiotic errors cause aneuploidy; how aneuploidy causes meiotic errors. Curr Opin Genet Dev 16: 323-329, 2006. PMID: 16647844.

3 Tartaglia NR, Howell S, Sutherland A, Wilson R and Wilson L: A review of trisomy X $(47, \mathrm{XXX})$. Orphanet J Rare Dis 5: 8, 2010. PMID: 20459843. DOI: 10.1186/1750-1172-5-8

4 Hamerton JL, Canning N, Ray M and Smith S: A cytogenetic survey of 14,069 newborn infants. I. Incidence of chromosome abnormalities. Clin Genet 8: 223-243, 1975. PMID: 1183067. DOI: $10.1111 / \mathrm{j} .1399-0004.1975 . t b 01498 . x$

5 Otter M, Schrander-Stumpel CT and Curfs LM: Triple X syndrome: A review of the literature. Eur J Hum Genet 18: 265271, 2010. PMID: 19568271. DOI: 10.1038/ejhg.2009.109 
6 Tartaglia NR, Ayari N, Hutaff-Lee C and Boada R: Attentiondeficit hyperactivity disorder symptoms in children and adolescents with sex chromosome aneuploidy: XXY, XXX, XYY, and XXYY. J Dev Behav Pediatr 33: 309-318, 2012. PMID: 22333574. DOI: 10.1097/DBP.0b013e31824501c8

7 Wigby K, D’Epagnier C, Howell S, Reicks A, Wilson R, Cordeiro L and Tartaglia N: Expanding the phenotype of triple $\mathrm{X}$ syndrome: A comparison of prenatal versus postnatal diagnosis. Am J Med Genet A 170: 2870-2881, 2016. PMID: 27644018. DOI: 10.1002/ajmg.a.37688

8 Goswami R, Goswami D, Kabra M, Gupta N, Dubey S and Dadhwal V: Prevalence of the triple $\mathrm{X}$ syndrome in phenotypically normal women with premature ovarian failure and its association with autoimmune thyroid disorders. Fertil Steril 80: 1052-1054, 2003. PMID: 14556833. DOI: 10.1016/s0015-0282(03)01121-x

9 Stagi S, Di Tommaso M, Scalini P, Sandini E, Masoni F, Chiarelli F, Verrotti A, Giglio S, Romano S and de Martino M: Cross-sectional study shows that impaired bone mineral status and metabolism are found in nonmosaic triple $\mathrm{X}$ syndrome. Acta Paediatr 106: 619-626, 2017. DOI: 10.1111/apa.13744

10 Haverty CE, Lin AE, Simpson E, Spence MA and Martin RA: 47,XXX associated with malformations. Am J Med Genet A 125A: 108-111, 2004. PMID: 14755479. DOI: 10.1002/ajmg.a.20393

11 Ferrazzo KL, Payeras MR, Ferrazzo VA and Mezomo MB: Craniofacial and dental manifestations of triple $\mathrm{X}$ syndrome associated with congenital hypothyroidism: A case report. Spec Care Dentist 34: 156-159, 2014. PMID: 24117978. DOI: $10.1111 / \mathrm{scd} .12050$

12 Patiño-García A, López de Mesa R, de Alava E and Sierrasesúmaga L: Clinical and molecular features of Ewing sarcoma in a patient with triple-X syndrome. Cancer Genet Cytogenet 113: 188-190, 1999. PMID: 10484990.

13 Lee JH, Kim KS and Cho YG: A case of torsion of a mucinous cystadenoma in triple-X syndrome with pure gonadal dysgenesis. Arch Gynecol Obstet 274: 174-177, 2006. PMID: 16408186. DOI: 10.1007/s00404-005-0116-9

14 Sahinturk S, Ozemri Sag S, Ture M, Gorukmez O, Topak A, Yakut $\mathrm{T}$ and Gulten $\mathrm{T}$ : A fertile patient with $45 \mathrm{X} / 47 \mathrm{XXX}$ mosaicism. Genet Couns 26: 29-34, 2015. PMID: 26043504.

15 Iskender C, Tarım E, Cok T, Yalcinkaya C, Kalaycı H and Sahin F: Fetal axillary cystic hygroma: a novel association with triple X syndrome. Birth Defects Res A Clin Mol Teratol 94: 955-957, 2012. PMID: 23109196. DOI: 10.1002/bdra.23083

16 Kemp B, Hauptmann S, Schröder W, Amo-Takyi B, Leeners B and Rath W: Dysgerminoma of the ovary in a patient with triple-X syndrome. Int J Gynaecol Obstet 50: 51-53, 1995. PMID: 7556861. DOI:10.1016/0020-7292(95)02395-s

17 Becher R, Mahmoud HK, Schaefer UW and Schmidt CG: Transplantation of bone marrow with constitutional chromosomal anomalies. Cytogenetic studies and clinical implications. Blut 53: 341-346, 1986. PMID: 3530353. DOI: 10.1007/bf00320894

18 Sharapova SO, Valochnik AV, Guryanova IE, Sakovich IS and Aleinikova OV: Novel biallelic ATM mutations coexist with a mosaic form of triple $\mathrm{X}$ syndrome in an 11-year-old girl at remission after T-cell acute leukemia. Immunogenetics 70: 613617, 2018. PMID: 29492593. DOI: 10.1007/s00251-018-1056-4

19 Hall DA and Berry-Kravis E: Fragile X syndrome and fragile $\mathrm{X}$-associated tremor ataxia syndrome. Handb Clin Neurol 147: 377-391, 2018. PMID: 29325626. DOI: 10.1016/B978-0-44463233-3.00025-7
20 Lubs HA: A marker X chromosome. Am J Hum Genet 21: 231244, 1969. PMID: 5794013.

21 Sutherland GR: Routine diagnostic detection of the fragile X. J Med Genet 21: 74-75, 1984. PMID: 6694192. DOI: 10.1136/jmg.21.1.74-a

22 Sutherland GR and Richards RI: Unusual inheritance patterns due to dynamic mutation in fragile $\mathrm{X}$ syndrome. Ciba Found Symp 197: 119-126, 1996. PMID: 8827371. DOI: 10.1002/9780470514887.ch7

23 Sutherland GR: The fragile X chromosome. Int Rev Cytol 81: 107-143, 1983. PMID: 6347931. DOI: 10.1016/s00747696(08)62336-0

24 Martin JP and Bell J: A pedigree of mental defect showing sexlinkage. J Neurol Psychiatry 6: 154-157, 1943. PMID: 21611430. DOI: 10.1136/jnnp.6.3-4.154

25 Rocchi M, Archidiacono N and Filippi G: X-linked mental retardation. I. Martin-Bell syndrome (report of 18 families). J Genet Hum 35: 351-379, 1987. PMID: 3437265.

26 O'Byrne JJ, Sweeney M, Donnelly DE, Lambert DM, Beattie $\mathrm{ED}$, Gervin CM, Barton DE and Lynch SA: Incidence of fragile X syndrome in Ireland. Am J Med Genet A 173: 678-683, 2017. PMID: 28157260. DOI: 10.1002/ajmg.a.38081

27 Schwartz CE, Phelan MC, Pulliam LH, Wilkes G, Vanner LV, Albiez KL, Potts WA, Rogers RC, Schroer RJ, Saul RA, Prouty LA, Dean JH, Taylor HA and Stevenson RE: Fragile $\mathrm{X}$ syndrome: Incidence, clinical and cytogenetic findings in the black and white populations of South Carolina. Am J Med Genet 30: 641-654, 1988. PMID: 3177476. DOI: 10.1002/ ajmg. 1320300165

28 Laxova R: Fragile X syndrome. Adv Pediatr 41: 305-342, 1994. PMID: 7992687.

29 Simko A, Hornstein L, Soukup S and Bagamery N: Fragile X syndrome: recognition in young children. Pediatrics 83: 547552, 1989. PMID: 2927995.

30 Wheeler AC, Wylie A, Villagomez A, Bishop E and Raspa M: Health care for individuals with fragile $\mathrm{X}$ Syndrome: Understanding access and quality. Disabil Health J 12: 269-277, 2019. PMID: 30442576. DOI: 10.1016/j.dhjo.2018.11.004

31 Paulson H: Repeat expansion diseases. Handb Clin Neurol 147: 105-123, 2018. PMID: 29325606. DOI: 10.1016/B978-0-44463233-3.00009-9

32 Sauna-Aho O, Bjelogrlic-Laakso N, Siren A and Arvio M: Signs indicating dementia in Down, Williams and fragile $X$ syndromes. Mol Genet Genomic Med 6: 855-860, 2018. PMID: 29971948. DOI: $10.1002 / \mathrm{mgg} 3.430$

33 Heulens I, Suttie M, Postnov A, De Clerck N, Perrotta CS, Mattina T, Faravelli F, Forzano F, Kooy RF and Hammond P: Craniofacial characteristics of fragile $\mathrm{X}$ syndrome in mouse and man. Eur J Hum Genet 21: 816-823, 2013. PMID: 23211703. DOI: 10.1038/ejhg.2012.265

34 Oberlé I, Rousseau F, Heitz D, Kretz C, Devys D, Hanauer A, Boué J, Bertheas MF and Mandel JL: Instability of a 550-base pair DNA segment and abnormal methylation in fragile $\mathrm{X}$ syndrome. Science 252(5009): 1097-1102, 1991. PMID: 2031184. DOI:10.1126/science.252.5009.1097

35 Kremer EJ, Pritchard M, Lynch M, Yu S, Holman K, Baker E, Warren ST, Schlessinger D, Sutherland GR and Richards RI: Mapping of DNA instability at the fragile $\mathrm{X}$ to a trinucleotide repeat sequence $\mathrm{p}(\mathrm{CCG}) \mathrm{n}$. Science 252(5013): 1711-1714, 1991. PMID: 1675488. DOI: 10.1126/science.1675488 
36 Verkerk AJ, Pieretti M, Sutcliffe JS, Fu YH, Kuhl DP, Pizzuti A, Reiner O, Richards S, Victoria MF, Zhang FP, Eussen BE, van Ommen GJB, Blonden LAJ, Riggins GJ, Chastain JL, Kunst CB, Galjaard H, Caskey CT, Nelson DL, Oostraa BA and Warren ST: Identification of a gene $(F M R-1)$ containing a CGG repeat coincident with a breakpoint cluster region exhibiting length variation in fragile X syndrome. Cell 65: 905-914, 1991. PMID: 1710175. DOI: 10.1016/0092-8674(91)90397-h

37 Meijer H, de Graaff E, Merckx DM, Jongbloed RJ, de DieSmulders CE, Engelen JJ, Fryns JP, Curfs PM and Oostra BA: A deletion of $1.6 \mathrm{~kb}$ proximal to the CGG repeat of the FMRI gene causes the clinical phenotype of the fragile $\mathrm{X}$ syndrome. Hum Mol Genet 3: 615-620, 1994. PMID: 8069307. DOI: 10.1093/hmg/3.4.615

38 Chiurazzi P, Kozak L and Neri G: Unstable triplets and their mutational mechanism: size reduction of the CGG repeat $v s$. germline mosaicism in the fragile $\mathrm{X}$ syndrome. Am $\mathrm{J}$ Med Genet 51: 517-521, 1994. PMID: 7943033. DOI: 10.1002/ ajmg.1320510446

39 Gedeon AK, Baker E, Robinson H, Partington MW, Gross B, Manca A, Korn B, Poustka A, Yu S, Sutherland GR and Mully JC: Fragile $\mathrm{X}$ syndrome without CCG amplification has an FMR1 deletion. Nat Genet 1: 341-344, 1992. PMID: 1302032. DOI: $10.1038 / n g 0892-341$

40 Hagerman RJ, Van Housen K, Smith AC and McGavran L: Consideration of connective tissue dysfunction in the fragile $\mathrm{X}$ syndrome. Am J Med Genet 17: 111-121, 1984. PMID: 6711590. DOI: $10.1002 /$ ajmg.1320170106

41 Schultz-Pedersen S, Hasle H, Olsen JH and Friedrich U: Evidence of decreased risk of cancer in individuals with fragile X. Am J Med Genet 103: 226-230, 2001. PMID: 11745995.

42 Rosales-Reynoso MA, Ochoa-Hernández AB, AguilarLemarroy A, Jave-Suárez LF, Troyo-Sanromán R and BarrosNúñez P: Gene expression profiling identifies WNT7A as a possible candidate gene for decreased cancer risk in fragile $\mathrm{X}$ syndrome patients. Arch Med Res 41: 110-118.e2, 2010. PMID: 20470940. DOI: 10.1016/j.arcmed.2010.03.001

43 Sund R, Pukkala E and Patja K: Cancer incidence among persons with fragile $\mathrm{X}$ syndrome in Finland: A population-based study. J Intellect Disabil Res 53: 85-90, 2009. PMID: 18705633. DOI: $10.1111 / j .1365-2788.2008 .01116 . x$

44 Lucá R, Averna M, Zalfa F, Vecchi M, Bianchi F, La Fata G, Del Nonno F, Nardacci R, Bianchi M, Nuciforo P, Munck S, Parrella P, Moura R, Signori E, Alston R, Kuchnio A, Farace MG, Fazio VM, Piacentini M, De Strooper B, Achsel T, Neri G, Neven P, Evans DG, Carmeliet P, Mazzone M and Bagni C: The fragile $\mathrm{X}$ protein binds mRNAs involved in cancer progression and modulates metastasis formation. EMBO Mol Med 5: 1523-1536, 2013. PMID: 24092663. DOI: 10.1002/ emmm.201302847

45 Au WY, Man C, Pang A and Kwong YL: Acute lymphoblastic leukemia in a patient with fragile $\mathrm{X}$ syndrome: Cytogenetic and molecular features. Haematologica 88: ECR13, 2003. PMID: 12681986.

46 Collins DT, Mannina EM and Mendonca M: Total body irradiation in a patient with fragile $\mathrm{X}$ syndrome for acute lymphoblastic leukemia in preparation for stem cell transplantation: A case report and literature review. Am J Med Genet A 167A: 2444-2446, 2015. PMID: 26097012. DOI: 10.1002/ajmg.a.37204
47 Phelan MC, Stevenson RE, Collins JL and Trent HE $3^{\text {rd: }}$ Fragile X syndrome and neoplasia. Am J Med Genet 30: 77-82, 1988. PMID: 2845782.

48 Rodewald L, Miller DC, Sciorra L, Barabas G, Lee ML, Opitz, JM and Reynolds JF: Central nervous system neoplasm in a young man with Martin-Bell syndrome - fra(X)-XLMR. Am J Med Genet 26: 7-12, 1987. PMID: 3812581. DOI: 10.1002/ajmg.1320260103

49 Cunningham $\mathrm{M}$ and Dickerman JD: Fragile $\mathrm{X}$ syndrome and acute lymphoblastic leukemia. Cancer 62: 2383-2386, 1988. PMID: 3179954. DOI:10.1002/1097-0142(19881201)62:11<2383::aidcncr2820621122>3.0.co;2-r

50 Ferrari A, Meazza C and Casanova M: Nasopharyngeal carcinoma in a boy with fragile $\mathrm{X}$ syndrome. Pediatr Hematol Oncol 17: 597-600, 2000. PMID: 11033736.

51 Wirojanan J, Kraff J, Hawkins DS, Laird C, Gane LW, Angkustsiri K, Tassone F, Hagerman RJ: Two boys with fragile $\mathrm{X}$ syndrome and hepatic tumors. J Pediatr Hematol Oncol 30: 239-241, 2008. PMID: 18376289. DOI: 10.1097/MPH.0b01 $3 \mathrm{e} 31815 \mathrm{f} 88 \mathrm{c} 9$

52 Alexiou GA, Siozos G, Stefanaki K, Vlachakis E, Sfakianos G, Prodromou N and Moschovi M: Medulloblastoma in a child with fragile X syndrome. Neuropediatrics 43: 155-158, 2012. PMID: 22605614. DOI: $10.1055 / \mathrm{s}-0032-1315430$

53 Nielsen KB: Sex chromosome aneuploidy in fragile $X$ carriers. Am J Med Genet 23: 537-544, 1986. PMID: 3953664.

54 Fuster C, Templado C, Miró R, Barrios L and Egozcue J: Concurrence of the triple-X syndrome and expression of the fragile site Xq27.3. Hum Genet 78: 293, 1988. PMID: 3346020. DOI: $10.1007 /$ bf00291682

55 Watson MS, Breg WR, Pauls D, Brown WT, Carroll AJ, Howard-Peebles PN, Meryash D and Shapiro LR: Aneuploidy and the fragile X syndrome. Am J Med Genet 30: 115-121, 1988. PMID: 2972203.

56 Hoyos LR and Thakur M: Fragile X premutation in women: recognizing the health challenges beyond primary ovarian insufficiency. Assist Reprod Genet 34: 315-323, 2017. PMID: 27995424. DOI: 10.1007/s10815-016-0854-6

57 Stagi S, Iurato C, Lapi E, Cavalli L, Brandi ML and de Martino M: Bone status in genetic syndromes: a review. Hormones 14: 19-31, 2015. PMID: 25885101. DOI: 10.1007/BF03401378

58 Hang JF and Chen PC: Parosteal osteosarcoma. Arch Pathol Lab Med 138: 694-699, 2014. PMID: 24786129. DOI: 10.5858/arpa.2013-0030-RS

59 Giam $M$ and Rancati G: Aneuploidy and chromosomal instability in cancer: a jackpot to chaos. Cell Div 10: 3, 2015. PMID: 26015801. DOI: 10.1186/s13008-015-0009-7

60 Ganmore I, Smooha G and Izraeli S: Constitutional aneuploidy and cancer predisposition. Hum Mol Genet 2009 18(R1): R84R93, 2009. PMID: 19297405. DOI: $10.1093 / \mathrm{hmg} / \mathrm{ddp} 084$

61 Lichtenstein L: Polyostotic fibrous dysplasia. Arch Surg 36: 874-898, 1938. DOI: 10.1001/archsurg.1938.01190230153012

62 Lichtenstein L and Jaffe HL: Fibrous dysplasia of bone. A condition affecting one, several or many bones, the graver cases of which may present abnormal pigmentation of skin, premature sexual development, hyperthyroidism or still other extraskeletal abnormalities. Arch Pathol 33: 777-816, 1942.

63 Rao VV, Schnittger S and Hansmann I: G protein Gs alpha (GNAS1), the probable candidate gene for Albright hereditary osteodystrophy, is assigned to human chromosome 20q12- 
q13.2. Genomics 10: 257-261, 1991. PMID: 1904395. DOI: 10.1016/0888-7543(91)90508-c

64 Weinstein LS, Chen M and Liu J: Gs(alpha) mutations and imprinting defects in human disease. Ann N Y Acad Sci 968: 173-197, 2002. PMID: 12119276. DOI: 10.1111/j.17496632.2002.tb04335.x

65 Szuhai K, Cleton-Jansen AM, Hogendoorn PC and Bovée JV: Molecular pathology and its diagnostic use in bone tumors. Cancer Genet 205:193-204, 2012. PMID: 22682618. DOI: 10.1016/j.cancergen.2012.04.001

66 McCune DJ: Osteotis fibrosa cystica: the case of a nine year old girl who also exhibits precocious puberty, multiple pigmentation of the skin and hyperthyroidism. Am J Dis Child 52: 743-747, 1936.

67 Albright F, Butler AM, Hampton AO and Smith P: Syndrome characterized by osteitis fibrosa disseminata, areas of pigmentation and endocrine dysfunction, with precocious puberty in females. Report of five cases. N Engl J Med 216: 727- 746, 1937. DOI: 10.1056/NEJM193704292161701

68 Javaid MK, Boyce A, Appelman-Dijkstra N, Ong J, Defabianis P, Offiah A, Arunde P, Shaw N, Pos VD, Underhil A, Portero D, Heral L, Heegaard AM, Masi L, Monsell F, Stanton R, Dijkstra PDS, Brandi ML, Chapurlat R, Hamdy NAT and Collins MT: Best practice management guidelines for fibrous dysplasia/McCune-Albright syndrome: a consensus statement from the FD/MAS international consortium. Orphanet J Rare Dis 14:139, 2019. PMID: 31196103. DOI: 10.1186/s13023-0191102-9

69 Lecumberri B, Pozo-Kreilinger JJ, Esteban I, Gomes M, Royo A, Gómez de la Riva Á and Pérez de Nanclares G: Head and neck manifestations of an undiagnosed McCune-Albright syndrome: clinicopathological description and literature review. Virchows Arch 473: 645-648, 2018. PMID: 29984378. DOI: 10.1007/s00428-018-2396-z

70 Riminucci M, Liu B, Corsi A, Shenker A, Spiegel AM, Robey PG and Bianco P: The histopathology of fibrous dysplasia of bone in patients with activating mutations of the Gs alpha gene: sitespecific patterns and recurrent histological hallmarks. J Pathol 187: 249-258, 1999. PMID:10365102. DOI: 10.1002/(SICI)10969896(199901)187:2<249::AID-PATH222>3.0.CO;2-J

71 Marie PJ: Cellular and molecular basis of fibrous dysplasia. Histol Histopathol 16: 981-988, 2001. PMID: 11510989. DOI: 10.14670/HH-16.981

72 Pereira TDSF, Gomes CC, Brennan PA, Fonseca FP and Gomez RS: Fibrous dysplasia of the jaws: Integrating molecular pathogenesis with clinical, radiological, and histopathological features. J Oral Pathol Med 48: 3-9, 2019. PMID: 30376190. DOI:10.1111/jop.12797

73 Macdonald-Jankowski DS and Li TK: Fibrous dysplasia in a Hong Kong community: The clinical and radiological features and outcomes of treatment. Dentomaxillofac Radiol 38: 63-72, 2009. PMID: 19176647 . DOI: $10.1259 / \mathrm{dmfr} / 56740531$

74 Papadakis GZ, Millo C, Sadowski SM, Karantanas AH, Bagci $\mathrm{U}$ and Patronas NJ: Fibrous dysplasia mimicking malignancy on ${ }^{68} \mathrm{Ga}$-DOTATATE PET/CT. Clin Nucl Med 42: 209-210, 2017. PMID: 28072620. DOI: 10.1097/RLU.000000000 0001527

75 De Coster L, Sciot R, Everaerts W, Gheysens O, Verscuren R, Deroose CM, Pans S, Van Laere K and Goffin KE: Fibrous dysplasia mimicking bone metastasis on ${ }^{68} \mathrm{GA}$-PSMA PET/
MRI. Eur J Nucl Med Mol Imaging 44: 1607-1608, 2017. PMID: 28488027. DOI: 10.1007/s00259-017-3712-6

76 Lee H, Lee KS and Lee WW: ${ }^{18} \mathrm{~F}-\mathrm{NaF}$ PET/CT findings in fibrous dysplasia. Clin Nucl Med 40: 912-914, 2015. PMID: 26444650. DOI: 10.1097/RLU.0000000000000948

78 Hennessy G, Shetty D, Loh H, Bui C, Le K and Mansberg R: Polyostotic fibrous dysplasia in McCune-Albright syndrome demonstrated on ${ }^{68} \mathrm{Ga}$-DOTATATE PET/CT. Clin Nucl Med 41: 982-985, 2016. PMID: 27740949. DOI: 10.1097/RLU.000000000 0001372

79 Martini M, Klausing A, Heim N, Fischer HP, Sommer A and Reich RH: Fibrous dysplasia imitating malignancy. J Craniomaxillofac Surg 46: 1313-1319, 2018. PMID: 29859820. DOI: $10.1016 /$ j.jcms.2018.05.019

80 Ogul $\mathrm{H}$ and Keskin E: Locally aggressive fibrous dysplasia mimicking malign calvarial lesion. J Craniofac Surg 29: e318e319, 2018. PMID: 29485574. DOI: 10.1097/SCS.0000000 000004453

81 Tao L, Sun J, Jain A, Ouyang J and Tambunan D: Polyostotic fibrous dysplasia mimicking osseous metastases. Cureus 11: e3884, 2019. PMID: 30899635. DOI: 10.7759/cureus.3884

82 Worth HM and Stoneman DW: Osteomyelitis, malignant disease, and fibrous dysplasia. Some radiologic similarities and differences. Dent Radiogr Photogr 50: 1-8 and 12-15, 1977. PMID: 264832.

83 Collins MT, Singer FR and Eugster E: McCune-Albright syndrome and the extraskeletal manifestations of fibrous dysplasia. Orphanet J Rare Dis 7 Suppl 1: S4, 2012. PMID: 22640971. DOI: 10.1186/1750-1172-7-S1-S4

84 Pilheu F and Del Soldato G: Fibro-osteosarcoma of the jaw in a case of polyostotic fibrous dysplasia. Oral Surg Oral Med Oral Pathol 21: 778-781, 1966. PMID: 5219668. DOI: 10.1016/0030-4220(66)90101-0

85 Gross CW and Montgomery WW: Fibrous dysplasia and malignant degeneration. Arch Otolaryngol 85: 653-657, 1967. PMID: 6024495.

86 Slow IN and Friedman EW: Osteogenic sarcoma arising in a preexisting fibrous dysplasia: report of case. J Oral Surg 29: 126-129, 1971. PMID: 5279098.

87 Immenkamp M: Malignant change in fibrous dysplasia (author's transl). Z Orthop Ihre Grenzgeb 113: 331-343, 1975 (Article in German). PMID: 1058566.

88 Pack SE, Al Share AA, Quereshy FA and Baur DA: Osteosarcoma of the mandible arising in fibrous dysplasia - A case report. J Oral Maxillofac Surg 74: 2229.e1-2229.e4, 2016. PMID: 27425882. DOI: 10.1016/j.joms.2016.06.174

89 Sugiura Y, Kanda H, Motoi N, Nomura K, Inamura K, Okada E, Matsumoto H, Shimoji T, Matsumoto S, Nakayama J, Takazawa Y, Ishikawa Y and Machinami R: Osteosarcoma arising in fibrous dysplasia, confirmed by mutational analysis of GNAS gene. Pathol Res Pract 214: 318-324, 2018. PMID: 29268950. DOI: 10.1016/j.prp.2017.10.018

90 Sasikumar A, Joy A, Pillai MRA, Alex TM and Narayanan G: ${ }^{68} \mathrm{Ga}$-PSMA PET/CT in osteosarcoma in fibrous dysplasia. Clin Nucl Med 42: 446-447, 2017. PMID: 28346248. DOI: 10.1097/RLU.0000000000001646

91 Oh SH, Kang JH, Seo YK, Kim JH, Choi YS and Hwang EH: Malignant transformation of fibrous dysplasia into angiosarcoma. Oral Radiol, 2019. PMID: 31368093. DOI: $10.1007 / \mathrm{s} 11282-019-00404-2$ 
92 Majoor BC, Boyce AM, Bovée JV, Smit VT, Collins MT, Cleton-Jansen AM, Dekkers OM, Hamdy NA, Dijkstra PS and Appelman-Dijkstra NM: Increased risk of breast cancer at a young age in women with fibrous dysplasia. J Bone Miner Res 33: 84-90, 2018. PMID: 28856726. DOI: 10.1002/jbmr.3286

93 Burke AB, Collins MT and Boyce AM: Fibrous dysplasia of bone: Craniofacial and dental implications. Oral Dis 23: 697708, 2017. PMID: 27493082. DOI: 10.1111/odi.12563

94 Akintoye SO, Boyce AM and Collins MT: Dental perspectives in fibrous dysplasia and McCune-Albright syndrome. Oral Surg Oral Med Oral Pathol Oral Radiol 116: e149-e155, 2013 PMID: 23953425. DOI: 10.1016/j.oooo.2013.05.023

95 Tan YC, Yu CC, Chang CN, Ma L and Chen YR: Optic nerve compression in craniofacial fibrous dysplasia: the role and indications for decompression. Plast Reconstr Surg 120: 19571962, 2007. PMID: 18090759. DOI: 10.1097/01.prs.000 0287338.28018.c7

96 Amit M, Collins MT, FitzGibbon EJ, Butman JA, Fliss DM and Gil Z: Surgery versus watchful waiting in patients with craniofacial fibrous dysplasia - a meta-analysis. PLoS One 6: e25179, 2011. PMID: 21966448. DOI: 10.1371/journal. pone.0025179

97 Bessho K, Tagawa T, Murata M and Komaki M: Monostotic fibrous dysplasia with involvement of the mandibular canal. Oral Surg Oral Med Oral Pathol 68: 396-400, 1989. PMID: 2797736. DOI: 10.1016/0030-4220(89)90135-7

98 Colella G, Giudice A, Siniscalchi G, Falcone U and Guastafierro S: Chin numbness: a symptom that should not be underestimated: A review of 12 cases. Am J Med Sci 337: 407410, 2009. PMID: 19359984. DOI: 10.1097/MAJ. 0b013e31819299fa

99 Friedrich RE: Mental neuropathy (numb chin syndrome) leading to diagnosis of metastatic mediastinal cancer. Anticancer Res 30: 1819-1821, 2010. PMID: 20592385.

100 Assaf AT, Jürgens TP, Benecke AW, Riecke B, Blessmann M, Zrnc TA, Much CC, Heiland $M$ and Friedrich RE: Numb chin syndrome: A rare and often overlooked symptom. J Oral Facial Pain Headache 28: 80-90, 2014. PMID: 24482791. DOI: 10.11607/jop.994

101 Friedrich RE, Heiland M, Assaf AT and Riecke B: Cone beam computed tomography in the differential diagnosis of mental neuropathy (numb chin syndrome) in metastatic colon cancer. Anticancer Res 33: 1757-1760, 2013. PMID: 23564829.

102 Grün P, Bandura P, Grün A, Sutter W, Meller O and Turhani D: Sensory disturbance along the inferior alveolar nerve as a first clinical sign of multiple florid cemento-osseous dysplasia of the mandible - A case report. Int J Surg Case Rep 53: 452-457, 2018. PMID: 30567067. DOI: 10.1016/j.ijscr.2018.11.036

103 Chen M, Yang C, Fang B, Zhang S and Xu K: Treatment of hemimandibular fibrous dysplasia with radical excision and immediate reconstruction with free double costochondral graft. J Oral Maxillofac Surg 68: 2000-2004, 2010. PMID: 20493608. DOI: $10.1016 /$ j.joms.2009.09.035

104 Villa VG: Fibrous dysplasia in the upper jaw undergoing myxomatous degeneration. Oral Surg Oral Med Oral Pathol 8: 400-404, 1955. PMID: 14370766.

105 Hara H, Ohishi M and Higuchi Y: Fibrous dysplasia of the mandible associated with large solitary bone cyst. J Oral Maxillofac Surg 48: 88-91, 1990. PMID: 2294217. DOI: 10.1016/0278-2391(90)90189-9
106 Lagundoye SB, Obisesan AA, Daramola JO and Oluwasanmi JO: Radiology of multiloculated fibrous dysplasia of the jaws. J Natl Med Assoc 69: 779-781, 1977. PMID: 752729.

107 Laurian N and Zohar Y: Polyostotic fibrous dysplasia of upper and lower jaws. Laryngoscope 80: 440-447, 1970. PMID: 5436963.

108 Assaf AT, Benecke AW, Riecke B, Zustin J, Fuhrmann AW, Heiland $M$ and Friedrich RE: Craniofacial fibrous dysplasia (CFD) of the maxilla in an 11-year old boy: a case report. J Craniomaxillofac Surg 40: 788-792, 2012. PMID: 22436487. DOI: $10.1016 /$ j.jcms.2012.02.016

109 Kos M, Luczak K, Godzinski J and Klempous J: Treatment of monostotic fibrous dysplasia with pamidronate. J Craniomaxillofac Surg 32: 10-15, 2004. PMID: 14729043.

110 Eversole LR, Sabes WR and Rovin S: Fibrous dysplasia: a nosologic problem in the diagnosis of fibro-osseous lesions of the jaws. J Oral Pathol 1: 189-220, 1972. PMID: 4199101.

111 Pollandt K, Engels C, Kaiser E, Werner M and Delling G: Gs alpha gene mutations in monostotic fibrous dysplasia of bone and fibrous dysplasia-like low-grade central osteosarcoma. Virchows Arch 439: 170-175, 2001. PMID: 11561757. DOI: $10.1007 / \mathrm{s} 004280100453$

112 Krusinskiene V, Alvesalo L and Sidlauskas A: The craniofacial complex in 47, XXX females. Eur J Orthod 27: 396-401, 2005. PMID: 16043476. DOI: 10.1093/ejo/cji016

113 Miura M, Kato N, Kojima H and Oguchi H: Triple-X syndrome accompanied by single maxillary central incisor: Case report. Pediatr Dent 15: 214-217, 1993. PMID: 8378162.

114 Hillebrand U, Mohr C and Plewa G: [Taurodontism in patients with sex chromosome anomalies]. Dtsch Z Mund Kiefer Gesichtschir 14: 187-189, 1990. (Article in German). PMID: 2102428.

115 Farach A, Farach LS and Paulino AC: Therapeutic challenges in treating patients with fragile $\mathrm{X}$ syndrome and neoplasia. Pediatr Blood Cancer 60: E153-E156, 2013. PMID: 23873828. DOI: $10.1002 /$ pbc. 24688

116 Loesch DZ, Lafranchi $M$ and Scott D: Anthropometry in Martin-Bell syndrome. Am J Med Genet 30: 149-164, 1988. PMID: 3177440. DOI: 10.1002/ajmg.1320300113

117 Butler MG, Pratesi R, Watson MS, Breg WR and Singh DN: Anthropometric and craniofacial patterns in mentally retarded males with emphasis on the fragile X syndrome. Clin Genet 44 : 129-138, 1993. PMID: 8275570.

118 Loesch DZ, Hay DA, and Sheffield LJ: Fragile X family with unusual digital and facial abnormalities, cleft lip and palate, and epilepsy. Am J Med Genet 44: 543-550, 1992. PMID: 1481805. DOI: $10.1002 /$ ajmg.1320440502

119 Doray B, Badila-Timbolschi D, Schaefer E, Fattori D, Monga B, Dott B, Favre R, Kohler M, Nisand I, Viville B, Kauffmann I, Bruant-Rodier C, Grollemund B, Rinkenbach R, Astruc D, Gasser B, Lindner V, Marcellin L, Flori E, Girard-Lemaire F and Dollfus H: Epidemiology of orofacial clefts (1995-2006) in France (Congenital Malformations of Alsace Registry). Arch Pediatr 19: 1021-1029, 2012. (Article in French). PMID: 22925539. DOI: $10.1016 /$ j.arcped 2012.07 .002

120 Hjalgrim H, Fisher Hansen B, Brondum-Nielsen K, Nolting D and Kjaer I: Aspects of skeletal development in fragile $\mathrm{X}$ syndrome fetuses. Am J Med Genet 95: 123-129, 2000. PMID: 11078561. DOI: 10.1002/1096-8628(20001113)95:2<123::aidajmg6>3.0.co;2-u 
121 Kjaer I, Hjalgrim H and Russell BG: Cranial and hand skeleton in fragile X syndrome. Am J Med Genet 100: 156-161, 2001. PMID: 11298378. DOI: 10.1002/ajmg.1226

122 Sabbagh-Haddad A, Haddad DS, Michel-Crosato E and Arita ES: Fragile X syndrome: panoramic radiographic evaluation of dental anomalies, dental mineralization stage, and mandibular angle. J Appl Oral Sci 24: 518-523, 2016. PMID: 27812623. DOI: 10.1590/1678-775720160170

123 Shellhart WC, Casamassimo PS, Hagerman RJ and Belanger GK: Oral findings in fragile X syndrome. Am J Med Genet 23: 179187, 1986. PMID: 3953646. DOI: 10.1002/ajmg.1320230112

124 Nunn JH and Durning P: Fragile X (Martin Bell) syndrome and dental care. Br Dent J 168: 160-162, 1990. PMID: 2138025. DOI: $10.1038 /$ sj.bdj.4807112

125 Quan F, Grompe M, Jakobs P and Popovich BW: Spontaneous deletion in the FMR1 gene in a patient with fragile $\mathrm{X}$ syndrome and cherubism. Hum Mol Genet 4: 1681-1684, 1995. PMID: 8541863. DOI: $10.1093 / \mathrm{hmg} / 4.9 .1681$

126 Friedrich RE, Scheuer HA, Zustin J and Grob T: Cherubism: A case report with surgical intervention. Anticancer Res 36: 31093115, 2016. PMID: 27272835.

127 Topazian RG and Costich ER: Familial fibrous dysplasia of the jaws: report of a case. J Oral Surg 23: 559-568, 1965. PMID: 14329537.

128 van Capelle CI, Hogeman PH, van der Sijs-Bos CJ, Heggelman BG, Idowu B, Slootweg PJ, Wittkampf AR and Flanagan AM: Neurofibromatosis presenting with a cherubism phenotype. Eur J Pediatr 166: 905-909, 2007. PMID: 17120035. DOI: 10.1007/s00431-006-0334-6
129 Mitchell JA, Wray J and Michalski K: Neurofibromatosis and fragile-X syndrome in the same patient. Am J Med Genet 22: 571-575, 1985. PMID: 3933345.

130 Watano K, Okamoto H, Takagi C, Matsuo H, Hirao N and Kitabatake A: Neurofibromatosis complicated with XXX syndrome and renovascular hypertension. J Intern Med 239: 531-535, 1996. PMID: 8656147. DOI: 10.1046/j.13652796.1996.422778000.x

131 Sujatha S and Jatti D: Neurofibromatosis and fibrous dysplasia manifesting in the same patient: a rare case report. J Investig Clin Dent 6: 77-80, 2015. PMID: 24000123. DOI:10.1111/jicd.12059

132 Arinami T, Kondo I, Hamaguchi H, Tamura K and Hirano T: A fragile X female with Down syndrome. Hum Genet 77: 92-94, 1987. PMID: 2957304. DOI: $10.1007 / b f 00284722$

133 Utine GE, Aktas D, Boduroğlu K, Alikasifoğlu M and Tunçbilek E: Coexistent mosaic monosomy 21 and fragile $\mathrm{X}$ syndrome in a mentally retarded male patient. Genet Couns 18 : 171-177, 2007. PMID: 17710869.

134 Lachiewicz AM, Hoegerman SF, Holmgren G, Holmberg E and Arinbjarnarson K: Association of the Robin sequence with the fragile X syndrome. Am J Med Genet 41: 275-278, 1991. PMID: 1789278. DOI: 10.1002/ajmg.1320410302

Received November 1, 2019

Revised November 13, 2019

Accepted November 14, 2019 